UDK 615.825:616.711

ORIGINAL ARTICLE

\section{Cheneau Brace In The Treatment Of Idiopathic Scoliosis}

\begin{abstract}
:
Introduction. Scoliosis is a three-dimensional deformity of the spine that requires a three-dimensional correction.
\end{abstract}

The aim of the paper. The aim was to evaluate the effectiveness of the Cheneau brace in the treatment of idiopathic scoliosis.

Patients and Methods. The retrospective study included 20 girls treated by the Cheneau brace. The criteria for inclusion were: double idiopathic thoracolumbar scoliosis over 20 degrees as measured by Cobb at the beginning of the treatment, continuous treatment with a brace and exercises controlled by an expert team until the end of growth and upon reaching skeletal maturity (Risser 5). The data were collected from medical records: age, the value of Cobb's angle and degree of bone maturity at the beginning and end of treatment. We analyzed changes in scoliosis at the end of treatment compared to the initial curve by examining the two radiographs made at the beginning and end of treatment. The change of scoliosis is described as: reduced, stabilized or worsened curvature. The success of the treatment is considered to be the reduction and stabilization of scoliosis.

Statistical analysis tool SPSS was used for result presentation and statistical inference.

Values $\mathrm{p}<0.05$ were considered statistically significant differences.

Results. Success in treatment (reduction / stabilization of scoliosis) was noted in $90 \%$ of the respondents. Thoracic scoliosis was reduced in $50 \%$ of patients, stabilized in $40 \%$, worsened in $10 \%$ of children. Reduction of lumbar scoliosis is in $70 \%$ and stabilization in $25 \%$ of patients. The average correction of thoracic scoliosis is six degrees $(p<0.002)$ and correction of lumbar scoliosis is eight degrees ( $p$ $<0.001)$. The average age at baseline was 12.7 years; girls have had approximately five braces changed during 4.5 years of treatment.

Conclusion. The results of this study confirm the efficiency of the Cheneau brace in the treatment of idiopathic scoliosis in $90 \%$ of patients.

Key words: idiopathic scoliosis, Cheneau brace

DOI: $10.7251 / S M D 1402063 D$

(Scr Med 2014:45:67-72)
Dobrinka Dragić ${ }^{1}$, Đurđica Stevanović-Papić ${ }^{1}$, Goran Talić ${ }^{1}$ Nataša Tomić ${ }^{1}$, Vladimira Šolaja-Koščica ${ }^{1}$

${ }^{1}$ Institute of Physical Medicine and Rehabilitation "Dr Miroslav Zotović", Banja Luka,

Republic of Srpska,

Bosnia and Herzegovina

Contact address:

Dobrinka Dragić

Institute of Physical Medicine and Rehabilitation "Dr Miroslav Zotović " Banja Luka, Slatinska 11 oo387 65687459 e-mailvedran_d@blic.net

Submitted: May 28th, 2014 Accepted: August, 9 th , 2014 


\section{Introduction}

Idiopathic adolescent scoliosis is a complex three-dimensional deformity of the spine, with the lateral curve in the frontal plane, rotation in transverse plane and profile change in the sagittal plane. ${ }^{1,2}$ Scoliosis is diagnosed by clinical examination, and treatment decisions are based on radiological findings. The standard parameter for assessing the curvature in the frontal plane is the Cobb angle. It is a leading factor in therapy evaluation, along with all the parameters that define child growth and development and the importance of curvature progression in the growth period. ${ }^{2}$ Risser sign defines bone maturity and the completion of growth. ${ }^{3}$ Conservative treatment of the scoliosis involves kinesitherapy, application of braces, radiological testing, regular monitoring of the flow of treatment, monitoring of the respiratory function and psychological support. ${ }^{4}$ The indication for a brace application is curvature of the spine of 20-45 degrees measured by Cobb and Risser sign of bone maturity up to three (3).

Scoliosis, as a three-dimensional deformity, requires a three-dimensional correction (3D), in all three anatomical planes. ${ }^{5,6}$ Among the more contemporary braces that satisfy this principle is the Cheneau brace.

\section{The aim of the paper}

The aim was to evaluate the effectiveness of the Cheneau brace in the treatment of adolescent idiopathic scoliosis.

\section{Patients and Methods}

The retrospective study included 20 girls treated by the Cheneau brace at the Institute of Physical Medicine and Rehabilitation “Dr Miroslav Zotović " in Banja Luka, in the period from 2006 to 2013. The girls were chosen randomly. Inclusion criteria for this research were: 1. double idiopathic thoracolumbar scoliosis over 20 degrees by Cobb at the beginning of treatment and 2. continuous treatment - Cheneau brace and exercises under the control of the team of experts until the cessation of growth and achieving bone maturity (Risser 5). The girls used the Cheneau brace for 22 hours a day and were exercising daily for two hours until the termination of the treatment.

The data for this study were taken from medical documentation: the girls' age at the beginning and end of the treatment, the value of Cobb angle and degree of bone maturity (Risser) at the beginning and end of the treatment, the number of the braces replaced by each girl. The average age of the children was determined at the beginning of the treatment, the average number of years in treatment and the number of the braces made.

The change of scoliosis was analyzed at the end of the treatment in comparison to the initial curvature by examining the two radiographs of the spine with the Risser sign displayed in posteroanterior at the end and beginning of the treatment. The thoracic and lumbar curvatures were measured by Cobb and the values of the curvatures for every child and each curvature at the beginning and end of the treatment were compared. Based upon the value changes of the Cobb angle on the two radiographs, the treatment outcome was defined:

1. the curvature reduction (for more than 5 degrees measured by Cobb)

2. the curvature stabilization (when the change was not more than 5 degrees)

3. the curvature deterioration (curve increased by more than 5 degrees).

The success of the treatment was considered to be the reduction and stabilization of scoliosis.

The degree of bone maturity was measured when the treatment began and was compared with the final outcome of treatment, when the treatment was completed and when the radiological bone growth verification of all patients was completed. The significance of the change and the success of treatment in children with high risk of progression of scoliosis (Risser under three) was evaluated.

Statistical analysis tool SPSS was used for result presentation and statistical inference.

Values $\mathrm{p}<0.05$ were considered statistically significant differences.

\section{Results}

In $90 \%$ of the examinees $[\mathrm{n}=18]$ in the research, with double thoracolumbar idiopathic scoliosis, the treatment with the application of the Cheneau brace and by continual exercising was successfully finished. Out of 20 thoracic curvatures, 18 of them were treated successfully, and one (1) out of 20 lumbar curvatures has deteriorated. The structure of the examinees and value change of the scoliotic curves measured by Cobb is available in Table 1.

Average thoracic scoliosis at the beginning of the treatment was 33.80 degrees and the lumbar scoliosis was 29.45 degrees. The average age at the beginning of the treatment was $12.7[\mathrm{SD}=1.29]$.

The greatest measured scoliosis were 45 degrees [ $\mathrm{n}=2]$, which were successfully controlled by the action of brace. The lowest scoliosis of 20 degrees $[n=3]$ became either reduced $[n=2]$ or deteriorated $[n=1$, lumbar scoliosis with Risser of 3]. Characteristic of the smallest lumbar curves (20 degrees) is that they are secondary curves, of primary major thoracic scoliosis (30-40 degrees), which were stabilized during the treatment (Table 1). The largest scoliosis at the end of the treatment was 40 degrees, in the 
thoracic segment $[\mathrm{n}=4]$, and the smallest was 10 degrees, in the lumbar segment [ $\mathrm{n}=5]$.

Table 1. Structure of the respondents and changes of findings

\begin{tabular}{|c|c|c|c|c|c|c|c|c|}
\hline \multirow{3}{*}{$\begin{array}{c}\text { Children } \\
1\end{array}$} & \multirow{3}{*}{$\begin{array}{c}\begin{array}{c}\text { Age } \\
\text { (year) }\end{array} \\
12\end{array}$} & \multirow{3}{*}{$\begin{array}{c}\text { Risser } \\
2 \\
\end{array}$} & \multirow{2}{*}{\multicolumn{2}{|c|}{$\begin{array}{c}\text { TSPTTSAT } \\
\text { (Cobb } \\
\text { angle) }\end{array}$}} & \multirow{2}{*}{\multicolumn{2}{|c|}{$\begin{array}{c}\text { LSPTLSAT } \\
\begin{array}{c}\text { (Cobb } \\
\text { angle) }\end{array} \\
\end{array}$}} & \multirow{3}{*}{$\begin{array}{l}\text { GT } \\
5\end{array}$} & \multirow{3}{*}{$\begin{array}{r}\text { BM } \\
5 \\
\end{array}$} \\
\hline & & & & & & & & \\
\hline & & & 44 & 40 & 40 & 35 & & \\
\hline 2 & 14 & 2 & 25 & 20 & 30 & 25 & 3 & 3 \\
\hline 3 & 13 & 0 & 42 & 25 & 23 & 10 & 4 & 5 \\
\hline 4 & 11 & 0 & 38 & 30 & 25 & 15 & 6 & 7 \\
\hline 5 & 11 & 0 & 35 & 30 & 31 & 20 & 6 & 6 \\
\hline 6 & 12 & 0 & 25 & 25 & 25 & 20 & 5 & 5 \\
\hline 7 & 13 & 0 & 26 & 14 & 34 & 25 & 4 & 5 \\
\hline 8 & 13 & 1 & 42 & 35 & 32 & 30 & 4 & 5 \\
\hline 9 & 11 & 0 & 22 & 30 & 34 & 23 & 6 & 7 \\
\hline 10 & 12 & 1 & 40 & 20 & 30 & 10 & 5 & 4 \\
\hline 11 & 14 & 2 & 29 & 19 & 25 & 15 & 3 & 4 \\
\hline 12 & 14 & 2 & 45 & 40 & 36 & 30 & 3 & 3 \\
\hline 13 & 14 & 3 & 28 & 21 & 24 & 10 & 3 & 3 \\
\hline 14 & 14 & 3 & 28 & 30 & 20 & 26 & 3 & 3 \\
\hline 15 & 13 & 3 & 40 & 20 & 20 & 10 & 4 & 3 \\
\hline 16 & 12 & 3 & 40 & 30 & 30 & 20 & 5 & 4 \\
\hline 17 & 11 & 0 & 26 & 20 & 30 & 30 & 6 & 7 \\
\hline 18 & 12 & 1 & 27 & 23 & 45 & 30 & 5 & 5 \\
\hline 19 & 14 & 3 & 44 & 40 & 35 & 25 & 3 & 3 \\
\hline 20 & 14 & 3 & 30 & 40 & 20 & 10 & 3 & 3 \\
\hline
\end{tabular}

Key: TPT-Thoracic scoliosis prior to treatment, TAT-Thoracic scoliosis after treatment,

LPT-Lumbar scoliosis prior to treatment, LAT-Lumbar scoliosis after treatment,

GT- Years of treatment, BM -Number of braces

On average, every girl changed five braces during growth and treatment (Table 1). The new braces were made once a year, usually every 10 months. All the girls finished their treatment at the age of 17 , and were treated for an average of 4.5 years.

The success in the treatment of scoliosis is considered to be the reduction and stopping (stabilization) of the scoliosis in progression. The thoracic curve was reduced (more than five degrees by Cobb) in $50 \%$ of patients [n $=10]$, and stabilized (change of scoliosis up to five degrees) in $40 \%$ [n=8], which made a success in treatment up to $90 \%$ of children $[n=18]$. Two curves deteriorated $(10 \%$ of the children) for more than 5 degrees (Table 2). The treatment was successful in $95 \%$ of the lumbar scoliosis $[\mathrm{n}=19]$.
Table 2. Result of treatment and Risser's sign

\begin{tabular}{|c|c|c|c|c|c|c|}
\hline \multirow{2}{*}{$\begin{array}{l}\text { Risser prior to treatment } \\
\text { Change of scoliosis after } \\
\text { treatment }\end{array}$} & & \multicolumn{5}{|c|}{ Risser } \\
\hline & & 0 & 1 & 2 & 3 & Total \\
\hline & $\mathrm{N}$ & 7 & 3 & 4 & 6 & 20 \\
\hline & $\%$ & 35.0 & 15.0 & 20.0 & 30.0 & 100.0 \\
\hline \multicolumn{7}{|l|}{ Thoracic scoliosis } \\
\hline \multirow{2}{*}{ Reduced } & $\mathrm{N}$ & 4 & 2 & 1 & 3 & 10 \\
\hline & $\%$ & 57.1 & 66.7 & 25.0 & 50.0 & 50.0 \\
\hline \multirow{2}{*}{ Stabilized } & $\mathrm{N}$ & 2 & 1 & 3 & 2 & 8 \\
\hline & $\%$ & 28.6 & 33.3 & 75.0 & 33.3 & 40.0 \\
\hline \multirow{2}{*}{ Deteriorated } & $\mathrm{N}$ & 1 & 0 & 0 & 1 & 2 \\
\hline & $\%$ & 14.3 & 0.0 & 0.0 & 16.7 & 10.0 \\
\hline \multicolumn{7}{|l|}{ Lumbar scoliosis } \\
\hline \multirow{2}{*}{ Reduced } & $\mathrm{N}$ & 5 & 2 & 2 & 5 & 14 \\
\hline & $\%$ & 71.4 & 66.7 & 50.0 & 83.3 & 70.0 \\
\hline \multirow{2}{*}{ Stabilized } & $\mathrm{N}$ & 2 & 1 & 2 & 0 & 5 \\
\hline & $\%$ & 28.6 & 33.3 & 50.0 & 0.0 & 25.0 \\
\hline \multirow{2}{*}{ Deteriorated } & $\mathrm{N}$ & 0 & 0 & 0 & 1 & 1 \\
\hline & $\%$ & 0.0 & 0.0 & 0.0 & 16.7 & 5.0 \\
\hline
\end{tabular}

The structure of patients at the beginning of the treatment shows that the potential for deterioration of the curve was great in 14 children (70\%), who had the Risser sign less than three (Risser <3). The treatment was successful in children who had the Risser sign 1 and 2 (Table 2). Reduction of the thoracic scoliosis was greatest in children with Risser sign $1(66 \%)[\mathrm{n}=7]$.

Reduction of the lumbar scoliosis was greatest in children with Risser sign 3 (83\%) [n=6].

Deterioration was noted in children with Risser sign $3[\mathrm{n}=$ $2]$ and $o[n=1]$.

Maximal correction of the scoliosis was 20 degrees [n=2], in children with the Risser sign 1 and 3 (Table 1). The minimum value of the correction, which is considered the improvement of the findings, is six degrees [ $\mathrm{n}=2]$, and is characterized by a diverse structure of patients (Risser zero and three, scoliosis less and greater than 30 degrees).

Reduction of the scoliosis up to five degrees is classified as the scoliosis stabilization and it is present in eight thoracic and five lumbar curves (Table 2).

By analyzing the value reductions of the thoracic curves in the overall sample (Table 3), the average reduction is 6.2 degrees $[\mathrm{n}=20, \mathrm{SD}=7.8]$. The average reduction of the lumbar curves is 8.5 degrees $[\mathrm{n}=20, \mathrm{SD}=5.7]$. 
Table 3. Average value of the scoliotic curves at the beginning and at the end of treatment

\begin{tabular}{|c|c|c|c|c|c|}
\hline $\begin{array}{l}\text { Scoliosis (Cobb } \\
\text { angle) }\end{array}$ & Mean & $\begin{array}{l}\text { Std. } \\
\text { Dev. }\end{array}$ & $\begin{array}{c}\text { Mean } \\
\text { Correction }\end{array}$ & $\begin{array}{l}\text { Std. } \\
\text { Dev. }\end{array}$ & $\begin{array}{c}\text { Std. } \\
\text { Error } \\
\text { Mean }\end{array}$ \\
\hline $\begin{array}{l}\text { Thoracic curve } \\
\text { prior to treatment }\end{array}$ & 33.80 & 7.84 & & & \\
\hline $\begin{array}{l}\text { Thoracic curve } \\
\text { after treatment }\end{array}$ & 27.60 & 8.16 & 6.20 & 7.79 & 1.7420 .002 \\
\hline $\begin{array}{l}\text { Lumbar curve } \\
\text { prior to treatment }\end{array}$ & 29.45 & 6.79 & & & \\
\hline $\begin{array}{l}\text { Lumbar curve } \\
\text { after treatment }\end{array}$ & 20.95 & 8.19 & 8.50 & 5.70 & 1.2760 .000 \\
\hline
\end{tabular}

The lumbar scoliosis are characterised by a greater percentage of reduced scoliosis, lower rate of deterioration (Table 2), and larger curvature correction (Table 3).

By analyzing the bone maturity at the beginning of the treatment with an average degree of curve correction, the greatest one was noted in children with Risser 1, which was average 12 degrees (Table 1 ).

\section{Discussion}

The research so far have shown that with the application of the braces we can change the progress of the scoliosis, ${ }^{[4,7,8]}$ and this paper also confirms the notion by proving the efficiency of the Cheneau brace. Primary goals in treating scoliosis are to reduce the curve and stop the progression of the curve, ${ }^{[4]}$ and that was accomplished at the end of treatment in $90 \%$ of the patients. Similar results are present in other researches, where the goal was accomplished in $86 \%{ }^{[9]}$ and $100 \%$ of patients. ${ }^{[10]}$

Correction of the curve is depicted differently in various studies. The results vary from $23 \%$ of the children, ${ }^{[1]} 26 \%$ [9] up to $69 \% .{ }^{[10]}$ The reduction of the thoracic curves in this research was noted in $50 \%$ of the children, and lumbar in $70 \%$, what proves the efficiency of the Cheneau brace, and is also within the results of other researches. In order for the brace to be effective, it has to be functional, must be worn regularly and the treatment should last until the end of growth. All the patients in this research followed the mentioned rules. In some researches, where children quitted their treatment or interrupted continuity of treatment, the results were worse. ${ }^{[12]}$

In this research, the lumbar scolioses were in higher percentage lowered in comparison to the thoracic, and are characterized by a larger correction of the curves, what other authors also state. ${ }^{[12]}$ Average curve correction (6.2 to 8.5 degrees) is in compliance with other researches. ${ }^{[10,11,12}$
${ }^{3}$ At the end of treatment the corrections from 6 degrees ${ }^{[12]}$ to 11 degrees $[\mathrm{SD}=7,4]^{[10]}$ are registered.

Stabilization of the curve in the studies varies from $15 \%$ ${ }^{[11]}$ to $60 \%$ of children. ${ }^{[9]}$ In this research there have been $40 \%$ of thoracic and $25 \%$ of lumbar curves stabilized, what is also in accordance with the average results of other researches. Scolioses of over 40 degrees were more frequent in thoracic segment $[\mathrm{n}=5]$, then the lumbar $[\mathrm{n}=$ 1]. They were stabilized at the end of the treatment, while other smaller curvatures in both segments were mainly reduced (Table 1).

There is a direct correlation between the growth potential and progression of the idiopathic scoliosis when the child is in the phase of accelerated growth and when both the body height and growth speed are prominent. ${ }^{[1]}$ The data from this research that all the patients who had Risser 1 and 2 at the beginning of the treatment successfully finished the treatment, indicate the positive effect of the Cheneau brace in long term treatment of idiopathic scoliosis, that by definition, have a great potential for deformity progression. Averagely, the girls wore the brace 4.5 years (Table 1 ) and regularly exercised, which, along with the braces function, emphasizes the importance of continual cooperation between the child, their parents and the expert.

By analyzing the degree of skeletal maturity at the beginning of the treatment with an average degree of the curve correction, the largest correction was noted in children with Risser 1, with the average correction of lumbar scolioses of 12 degrees, standing out the brace's possibilities in the phase of skeletal growth (Table 1).

By observing the maximal and minimal curvature corrections, in regard to the degree of skeletal maturity, there was no significant change in the structure of the patients, what confirms the importance of individual evaluation and treatment of every scoliosis and every child.

Literature emphasizes the decrease of surgical procedures using the brace. Frequency of the surgery of deformity is said to vary from $0 \%,{ }^{[10]} 0.9 \%,{ }^{[13]}$ to $3.8 \%{ }^{[14]}$ in the investigated groups.

The deteriorations in this research did not require any surgical procedure.

The success of this group of patients is a result of a great teamwork and the braces effectiveness. Long term application of the brace during growth, regular exercising and frequent examinations of the team of experts, participation of the parents and continual child support represent a precondition for a successful treatment. Changes in clinical findings of the spine during growth period and also the functionality of the brace require a constant control by the team of experts, individual evaluation, timely drafting 
of a new brace which, according to these results, has a good effect in the treatment of idiopathic scoliosis.

Limitations of this research are in regard to the small group of patients and the factors of inclusion that define the group with only the double scoliosis and the application of only one type of brace.

The positive side of this research is that all the patients from the mentioned group have finished their treatment, and the results that we have been provided with allow the insight in the therapeutic of one particular treatment protocol by applying only one brace type.

\section{Conclusion}

Successful treatment of idiopathic scoliosis with the application of the Cheneau brace was achieved in $90 \%$ of the patients. Scoliosis was reduced in $50 \%$ of thoracic and $70 \%$ of lumbar curves. Scoliosis was stopped in progression in $40 \%$ of thoracic and $25 \%$ of lumbar curves.

Deterioration in $10 \%$ of the patients did not lead to a surgical procedure. The greater is the degree of correction of the lumbar curves in relation to the thoracic curves. In all the patients with Risser sign 1 and 2 the medical findings were improved. This research proves the therapeutic effect of the Cheneau brace in treatment of the thoracic and lumbar idiopathic scolioses, as long as the brace is applied 22 hours a day and exercises are conducted regularly. The importance of continual application of the brace, physical therapy, team monitoring of the clinical findings and the braces effect emphasize the complexity in treatment of idiopathic scoliosis.

\section{References:}

1. Rigo M. Patient evaluation in idiopathic scoliosis: Radiographic assessment, trunk deformity and back asymmetry. Physiother Theory Pract 2011;27(1):7-25.

2. Rigo M, Grivas T. Rehabilitation schools for scoliosis thematic services: Describing the methods and results. Scoliosis2010;5:27.

3. Wang WW, Xia CW, Zhu F, et al. Correlation of Risser sign, radiographs of the hand and wrist with the histological grade of iliac crestapophysis in girls with adolescent idiopathic scoliosis. Spine2009;34(17):1849-54.

4. Negrini S, Minozzi S, Bettany-Saltikov J, Zaina F, et al. Braces for idiopathic scoliosis in adolescents. Cochrane Database of Systematic Reviews2010;(1):CDoo6850

5. Cheneau J. Scoliosis treating brace evaluation of our brace since 1970: An evaluation of the normalization of rotation, of rib static and of the wedge shaped vertebrae. Locomotor System 2003;1:2938 .

6. Kotwicki T, Cheneau J. Biomechanical action of a corrective brace on thoracic idiopathic scoliosis: Cheneau 2000 orthosis.Disabil Rehabilit Ass Technol 2008;3:3.

7. Negrini S, Grivas ThB, Kotwicki T, Rigo M, Zaina F. Standards of management of idiopathic scoliosis with corrective braces in everyday clinics and in clinical research: SOSORT Consensus 2008. Scoliosis2009;4:2.

8. Weiss HR, Weiss G, Scharr HJ. Incidence of surgery in conservatively treated patients with scoliosis.Ped Rehab 2003;6:111-118.

9. Pham VM, Herbaux B, Schill A, Thevenom A. Evaluation of the Chêneau brace in adolescent idiopathic scoliosis. Annales de Readaptation et de Medecine Physique 2007;50(3):125-33. DOI:10.1016/j.annrmp.2006.11.003

10. De Giorgi S, Piazzolla A, Tafuri S, Borracci C, Martucci A, De Giorgi G. Chêneau brace for adolescent idiopathic scoliosis: longterm results. Can it prevent surgery? Europen Spine Journal 2013;22(6):815-22.

11. Cinnella P, Muratore M, Testa E, Bondente PG. The treatment of adolescent idiopathic scoliosis with Cheneau brace: long term outcome. Scoliosis 2009;4(2):44.

12. Zaborowska SK, Kowalski I, KotwickiT,Protasiewicz-FałdowskaH. KiebzakW. Effectiveness of Chêneau brace treatment for idiopathic scoliosis: prospective study in 79 patients followed to skeletal maturity. Scoliosis 2011;6:2 doi:10.1186/1748-7161-6-2

13. Negrini S, Atanasio S, Zaina F, Romano M, Parzini S, Negrini A. End-growth results of bracing and exercises for adolescent idiopathic scoliosis. Prospective worst-case analysis.Stud Health Technol Inform2008;135:395-408.

14. Rigo M, Reiter C, Weiss HR. Effect of conservative management on the prevalence of surgery in patients with adolescent idiopathic scoliosis. Ped Rehab 2003;6:209-214.

\section{Cheneau mider u liječenju idiopatskih skolioza}

\section{SAŽETAK:}

Uvod. Skolioza je trodimenzionalni deformitet kičmenog stuba koji zahtijeva trodimenzionalnu korekciju.

Cilj rada. Utvrditi efikasnost Cheneau midera u liječenju idiopatskih skolioza. 
Ispitanici i metode. Retrospektivna studija obuhvatila je 20 djevojčica liječenih Cheneau miderom. Kriterijumi za uključivanje su bili: dvostruka idiopatska torakolumbalna skolioza preko 20 stepeni mjerena po Cobbu na početku liječenja, kontinuirano liječenje miderom i vježbama pod kontrolom stručnog tima do završetka rasta i dostizanja koštane zrelosti (Risser 5). Podaci su prikupljeni iz medicinske dokumentacije: uzrast, vrijednost Cobb-ovog ugla i stepen koštane zrelosti na početku i na kraju liječenja. Analizirana je promjena skolioze na kraju liječenja u odnosu na početnu krivinu uvidom u dva radiograma učinjena na početku i na kraju liječenja. Promjena skolioze je opisana kao: smanjena, stabilizovana ili pogoršana krivina. Uspjeh u liječenju je podrazumijevao smanjenje i stabilizaciju skolioze.

Za prikaz rezultata i statističko zaključivanje korišćen je analitičko-statistički alat SPSS. Statistički značajne razlike smatrane su vrijednosti $\mathrm{p}<0.05$.

Rezultati. Uspjeh u liječenju (smanjenje/stabilizacija skolioze) bio je kod 90\% ispitanika. Torakalna skolioza je smanjena kod $50 \%$ ispitanika, stabilizovana kod 40\%, pogoršana kod 10\% djece. Smanjenje lumbalne skolioze je kod 70\%, a stabilizacija kod $25 \%$ ispitanika. Prosječna korekcija torakalne skolioze je šest stepeni $(p<0.002)$, a korekcija lumbalne skolioze je osam stepeni (p<0.001). Prosječni uzrast na početku liječenja je 12,7 godina; djevojčice su prosječno promijenile pet midera tokom 4,5 godine liječenja.

Zaključak. Uspješno liječenje idiopatskih skolioza primjenom Cheneau midera u navedenom uzorku je ostvareno kod 90\% ispitanika.

Ključne riječi: idioptska skolioza, Cheneau mider 